\author{
Sławomir H. Zaręba \\ Uniwersytet Kardynała Stefana Wyszyńskiego w Warszawie \\ ORCID 0000-0001-7426-623X \\ Marcin Choczyński \\ Uniwersytet Kardynała Stefana Wyszyńskiego w Warszawie \\ ORCID 0000-0002-6636-9025
}

\title{
Warszawiacy w zwierciadle analiz socjologicznych PPPiW. Raport z badań wirtualizacji środowiska wielkomiejskiego w czasie pandemii 2021
}

Dandemia koronawirusa SARS-CoV-2 - wywołującego chorobę CoPid-19 - spowodowała globalne zmiany ludzkich form gromadzenia się, co z kolei zainicjowało modyfikacje samych więzi społecznych. Biorąc pod uwagę taki stan rzeczy, socjologowie z wielu ośrodków (zarówno typowo naukowych, jak i rynkowych, komercyjnych) wdrożyli dużą ilość projektów badawczych mających na celu opis globalnego dystansowania się i wpływu tego zjawiska na codzienne praktyki, strukturyzację grup, zrzeszeń i innych społecznych zbiorowości, a także specyfikę więzi. Rynek akademickich i eksperckich publikacji socjologicznych zapełnia się systematycznie nowymi pozycjami, opisami zachowań w warunkach społecznej izolacji, co dowodzi o doniosłości tego stanu rzeczy i wpływie na codzienne funkcjonowanie ${ }^{1}$. Ponadto cykliczne badanie opinii i nastrojów Polaków związanych z pandemią regularnie przeprowadza Centrum Badania Opinii Społecznej ${ }^{2}$ (CBOS), jak i prywatne instytuty badawcze. Zapewne temat ograniczeń społecznych wywołanych epidemią będzie ważną składową zaplanowanego na 2022 r. XVIII Zjazdu Socjologicznego, zatytułowanego

1 Por. K. Andrejuk, I. Grabowska, M. Olcoń-Kubicka, I. Taranowicz (red.), Zmiana spoteczna, pandemia, kryzys. Konteksty empiryczne i teoretyczne, Warszawa 2021.

2 Zob. M. Feliksiak, Opinie o epidemii koronawirusa i zwiazanych z niq restrykcjach, komunikat z badań CBOS, Warszawa 2020. 
Społeczeństwo przyszłości. Rekompozycje. Właśnie propozycje, aby na nowo opisać socjologicznie świat po pandemii, są najbardziej ciekawe i pokazują w jaki sposób systemy społeczne zareagowały na pojawienie się nowego, praktycznie niespotykanego od stu lat globalnego zagrożenia zdrowia publicznego. Socjologowie będą zastanawiać się, jak trwałe będą skutki epidemii i w jaki sposób odciśnie ona swoje piętno na praktykach społecznych, regułach komunikacji czy też funkcjonowania sfer publicznych, zakładających przecież kontakty face-to-face. Transmisja wirusa pobudziła także do stawiania pytań egzystencjalnych, także tych traktujących o sensie życia człowieka, jego misji cywilizacyjnej, zagrożeniach związanych z eksploatacją środowiska naturalnego oraz poszukiwania szans na wyjście z pandemii bez znaczących strat ludzkich.

\section{Idea wszechogarniającej wirtualizacji}

Zagadnienia przenoszenia praktycznie większości sfer ludzkich praktyk do sieci doczekały się wielu opracowań naukowych. W większości z nich badacze przedstawiają obecny obraz sytuacji otoczenia wirtualnego, a także kreślą scenariusze na przyszłość. Przede wszystkim zwraca się powszechnie uwagę na niedookreśloność informacji w sieci, co z kolei warunkuje stałą ich modyfikację, przemianę, reaktywność takich treści w nieskończonym wręcz kierunku³. Ponadto treści zamieszczone w przestrzeni wirtualnej są tam umocowane na stałe, a cenzura praktycznie nie istnieje, oprócz działań podejmowanych przez władze niedemokratycznych państw, takich jak np. Chińska Republika Ludowa.

Definiowanie zagadnień wirtualizacji opiera się przeważnie na połączeniu sfer znaczeniowych potencjalności i uabstrakcyjnienia - imitacyjności $z$ technologią informatyczną. Nie znaczy to jednak, że próby definiowania wirtualizacji jako procesu nie przebiegały już wcześniej, np. w kontekście rozwoju środków pieniężnych i ich symbolizacji ${ }^{4}$. Wirtualizacja przeniknęła zatem z języka wyłącznie technicznego (a ściślej - informatycznego) praktycznie do każdej innej sfery, ukazując tym samym pewien sposób formatowania treści kultury, edukacji, pracy, nauki czy rozrywki.

Można zatem stwierdzić, że ,wirtualność i wirtualizacja w dzisiejszym znaczeniu są zjawiskiem nowym, oryginalnym, stanowiąc połączenie

3 Por. K. Korab, „Filozofia i socjologia wirtualnej rzeczywistości”, w: K. Korab (red.), Wirtual. Czy nowy wspanialy świat?, Warszawa 2010, 21.

${ }_{4}$ Zob. M. Konopka, „Wirtualizacja - na styku techniki, organizacji i zarządzania”, Studia i Prace Kolegium Zarządzania i Finansów (2019), Zeszyt Naukowy nr 174 (2019) 67-68. 
symbolicznego mimetyzmu (byt wirtualny jako lustrzane odbicie świata realnego) z kreacją w przestrzeni cyfrowej tego, co nie ma swojego fizykalnego odpowiednika"s. Taki obraz wirtualizacji świadczy o jej modalności oraz zdolności do imitacyjnych względem świata realnego, którego jest w jakimś stopniu odzwierciedleniem, jednak tworząc również swój własny, odrębny świat.

Kontynuując definicyjne określenia wirtualizacji, można stwierdzić, że „wirtualność oznacza [...] cyfrowy charakter reprezentacji dowolnego obiektu lub procesu, zwykle połączony z jego obecnością w cyberprzestrzeni. Wirtualizacja polegałaby natomiast na komputerowym tworzeniu takich reprezentacji, ukazujących się ludzkiej naoczności jako byty swoiście realne pod postacią tzw. symulakrów". Takie ujęcie tej problematyki powoduje, że wirtualizacja stanowi nowy rodzaj komunikacji, platformę odniesień, również środek niezbędny w dużej mierze do zapewnienia sobie łączności ze światem w ogóle.

W niektórych opracowaniach tematycznych pojawiają się konkretne modele wirtualizacji organizacji czy też instytucji jako całości społecznych związanych w formę przedsiębiorstwa. Wskazuje się tutaj na obszary, takie jak wirtualizacja dostępu, aplikacji, procesów, pamięci masowych i sieci ${ }^{7}$. Widać zatem, że jest to proces obejmujący konkretne elementy składowe systemu. Co więcej - widoczna jest tutaj pewna segmentacja wirtualizowania konkretnych zasobów, począwszy właściwie od samego połączenia z siecią.

Jednak sferą, która w sposób znaczący poddała się wirtualizacji, jest z pewnością nabywanie dóbr konsumpcyjnych. Handel sieciowy jest współcześnie tym rynkiem, który kreuje trendy nie tylko sprzedażowe, ale też szerzej - ukazuje dążenie do określonego typu konsumpcji, której wirtualny korelat jest dla potencjalnych konsumentów bardzo atrakcyjny ${ }^{8}$, głównie poprzez rozszerzone możliwości - nie tylko prostej transakcji, nabycia

5 A. Pawłowski, „Wirtualizacja - historia i próba rekonstrukcji pojęcia”, w: L.W. Zacher (red.), Wirtualizacja. Problemy. Wyzwania. Skutki, Warszawa $2013,15$.

6 Tamże, 16.

7 Zob. M. Roszkowski, „Zastosowanie wirtualizacji do organizacji środowiska informatycznego społeczeństwa informacyjnego", Zeszyty Naukowe Uniwersytetu Szczecińskiego, nr 763, Ekonomiczne Problemy Ustug (2013) nr 105, 70.

8 Zob. W. Kuźniar, T. Surmacz, W. Szopiński, „Wirtualizacja konsumpcji i jej oddziaływanie na kształtowanie postaw i zachowań prosumpcyjnych wśród młodych konsumentów", Annales Universitatis Mariae Curie-Skłodowska, LublinPolonia, sectio h: Oeconomia, vol. LI (2017) nr 2, 149. 
określonego towaru, ale także jego promocji w mediach społecznościowych, pokazania też (i również promocji) samego siebie, jako osoby podążającej i kreującej pewne trendy (mody, ubioru, posiadania i ogólnie stylu życia). Wirtualizacja najwyraźniej obecna jest chyba w obrazkowej kulturze social mediów, gdzie to właśnie obrazy mogą stać się globalnie popularnymi memami (a w formie filmów viralami), wyrażającymi dobitnie pewien przekaz lub treść. Co nie może dziwić, taka forma współczesnej kultur jest w największym stopniu aprobowana przez pokolenia najmłodsze, dla których Internet rzeczywiście stał się światem równoległym, będącym koniecznym składnikiem ich codziennej egzystencji i budowania swojego obrazu w oczach rówieśników.

Wirtualizacja nie przebiegałaby w tak skokowy sposób, gdyby nie dostępność urządzeń mobilnych, dzięki którym całe społeczeństwa mają wręcz nieograniczony dostęp do sieci i usług przez nią oferowanych. Owa dostępność uwarunkowała specyficzne sposoby zaspokajania potrzeb konsumpcyjnych, które mają natychmiastową formę, co więcej, decydujące znaczenie zaczyna odgrywać tutaj ogólna dogodność oferowanych dóbr czy usług (dostarczenie przesyłek kurierem, płatności mobilne). Dlatego też pojawiło się wiele alternatyw wyborów konsumenckich, co przy wyłącznie stacjonarnej formie kultury często nie mogło zostać zrealizowane 9 .

Zaanonsowana dogodność jest praktycznie kluczowym zagadnieniem przyjęcia się wirtualizacji, jako procesu upraszczającego załatwianie wielu codziennych spraw, na serio wprowadziła ona perspektywę ,domocentryzmu", a także stale jest ona kompatybilna oraz adekwatna do stylu życia konsumentów ${ }^{10}$. Widać zatem wyraźnie, jak doskonale wirtualizacja sprawdziła się w sytuacji przymusowego lockdownu - stała się po prostu tym pragmatycznym, wręcz nieodzownym narzędziem komunikacji ze światem, który naraz stał się fizycznie mniej dostępny. Izolacja od świata i kreowanie „prywatnych lokalności”" życia dostępnego tu i teraz, gdzie wdrożenie wirtualizacji nie było tylko i wyłącznie wyborem, ale również stało się poniekąd koniecznością, szcze-

9 Zob. B. Kolny, „Wirtualizacja zachowań konsumentów na rynku usług zagospodarowujących czas wolny", Studia Ekonomiczne. Zeszyty Naukowe Uniwersytetu Ekonomicznego w Katowicach (2016) nr 302, 151.

10 Por. K. Włodarczyk, „Wirtualizacja konsumpcji polskiego społeczeństwa”, w: W. Patrzałek (red.), Konsumpcja jako forma komunikacji społecznej. Nowe paradygmaty $i$ konteksty badawcze, Prace Naukowe Uniwersytetu Ekonomicznego we Wrocławiu, Wrocław 2015, 239-242.

11 Por. M. Kowalska, „Wpływ wirtualizacji zachowań konsumenckich na rozwój domocentryzmu", Handel Wewnętrzny (2015) nr 6 (359), 67. 
gólnie dla osób pracujących w formule pracy zdalnej - tzw. home office. Skądinąd określenia te wyparły wcześniej stosowane ujęcie tzw. „telepracy”.

\section{Kontekst badań}

Szczególnie istotne wydaje się w tym kontekście analizowanie środowisk wielkomiejskich, najbardziej dotkniętych przez pandemiczne restrykcje, głównie z uwagi na skalę i gęstość zaludnienia, a także wynikające z tego faktu ograniczenia w dostępie do różnych publicznych przestrzeni (transport, rozrywka, nauka, praca, sport itp.). Ale jednocześnie taka forma izolacji może być „łagodzona” przez dostęp do wysokiej jakości świata wirtualnego (stabilne łącza, duża ilość operatorów internetowych, telewizyjnych, udogodnienia infrastrukturalne itp.). Taka perspektywa wydatnie przyczynia się do upowszechnienia zdalności, jako uniwersalnej praktyki szkolnej, akademickiej, pracowniczej czy też kulturalnej. W warunkach zagrożenia epidemicznego zdalność jest wprowadzana wszędzie tam, gdzie transmisja wirusa jest określana jako wysoka, a dotyczy to przede wszystkim aktywności publicznych (spotykanie się w zamkniętych przestrzeniach, nauczanie, konferencje i szkolenia). I to właśnie wszechogarniająca zdalność stała się tym zagadnieniem, któremu dokładnie chciał przyjrzeć się zespół badawczy. Zakładano, że respondenci wykażą w swoich wskazaniach stopień przeniesienia swoich relacji do sieci, a także opinie o postępującej wirtualizacji konkretnych obszarów społecznego i osobowego istnienia. Takie ujęcie pozwala też na przyjrzenie się jakości relacji, jakie przedstawiają respondenci z osobami o różnym stopniu związania (np. rodzina, przyjaciele, znajomi, współpracownicy).

Warto w tym miejscu zaznaczyć, że aktualne badanie socjologiczne jest kolejnym - już szesnastym - badaniem przeprowadzonym w ramach projektów badawczych realizowanych w pracowni Polskiego Pomiaru Postaw i Wartości (PPPiW), funkcjonującej w ramach Instytutu Nauk Socjologicznych UKSW, która istnieje od 2009 r. i ma na koncie eksplorację wielu obszarów tematycznych: np. udziału w kulturze (opis charakterystyki warszawskich edycji Europejskich Nocy Muzeów), badań etosów poszczególnych społeczności zawodowych (przedsiębiorców, urzędników, pielęgniarek i pielęgniarzy oraz prawników) czy też analizy środowisk parafialnych i badań kultury wielkomiejskiej (warszawskiej, bydgoskiej). Bardzo ważnym obszarem badań PPPiW są również środowiska młodzieży akademickiej, gdzie obserwuje się dynamiczne zmiany postaw i odniesień do współczesnych kwestii społecznych. Warto również zauważyć, że podejmowane tematy badawcze związane ze stołecznym środowiskiem 
społecznym są materiałem składającym się na znaczny dorobek serii publikacyjnej PPPiW ${ }^{12}$. Ponadto kontekst kultury wielkomiejskiej i wywodzących się z niej stylów życia również nadaje specyficznego znaczenia wirtualizacji codzienności mieszkańców Warszawy. Trzeba tutaj na pewno wyróżnić kompleksowość miejsca oraz kontaktów społecznych, jakie wynikają ze specyficznego urbanistycznego rozplanowania przestrzeni ${ }^{13}$.

Zatem kontekst badań został przyjęty niejako naturalnie, szczególnie biorąc pod uwagę doświadczenia badawcze zespołu PPPiW, jak również aktualną sytuację związaną z eksploracją socjologiczną zagadnienia pandemii, która to przyjmuje różne odcienie, a wielkomiejskie środowisko dodatkowo tę sytuację potęguje. Biorąc pod uwagę te uwarunkowania i konieczność stałego monitorowania postaw wybranych społeczności, tematyka badania okazała się nadzwyczaj ciekawa i jest kontynuacją wątków podnoszonych wcześniej, co daje badaniom PPPiW rys kontynuacji i ciągłości, ale także zbliża częściowo do charakterystyki tzw. badań longitudinalnych (wzdłuż czasu).

\section{Opis metodologii badań}

Ilościowe badanie socjologiczne zatytułowane Między światem realnym a wirtualnym. Mieszkańcy Warszawy w czasie pandemii zostało zrealizowane w miesiącach maj-czerwiec 2021 r. na próbie dorosłych mieszkańców Warszawy. Ostatecznie udało się uzyskać $\mathrm{N}=1102$ zwroty, a do analizy badawczej zakwalifikowano $n=606$ kwestionariuszy. Warunkiem dopuszczenia materiału do dalszych analiz była kompletność przekazanych przez respondentów danych. Tym razem zespół badawczy PPPiW (w składzie Sławomir H. Zaręba, Anna Linek, Martyna Kawińska, Joanna Wróblewska-Skrzek i Marcin Choczyński) został wzmocniony przez dołączenie osoby z zewnątrz - Małgorzaty Such-Pyrgiel. Kilku innych autorów zostało zaproszonych do sporządzenia opracowań danych zebranych z badania.

12 Należy tutaj wyróżnić przede wszystkim trzy pozycje dotyczące badań wybranych praktyk i zachowań warszawiaków: S.H. Zaręba, (red.), Lokalna wspólnota wyobrażona. Warszawa i jej mieszkańcy 2010, Warszawa 2012; S.H. Zaręba (red.), Warszawa: bunt i ucieczka w wielkim mieście. Światopoglad $i$ style życia młodych warszawiaków, Warszawa 2013 oraz R. Wiśniewski, S.H. Zaręba, M. Zarzecki (red.), W kierunku „kultury bez przemocy”. Diagnoza i przeciwdziałanie przemocy w Dzielnicy Bielany m.st. Warszawy, Warszawa 2016.

13 Zob. S.H. Zaręba, M. Choczyński, „Warszawa jako metropolia i centrum kultury", Uniwersyteckie Czasopismo Socjologiczne/Academic Journal of Sociology (2013) nr 8, 44. 
Obliczeń statystycznych w programie SPSS na bazie danych analitycznych uzyskanych w czasie trwania surveyu dokonała Joanna Wróblewska-Skrzek, natomiast Marcin Choczyński (w konsultacji z ekspertem - Katarzyną Uklańską, również pracownikiem naukowym Instytutu Nauk Socjologicznych UKSW) wprowadził strukturę ankiety do narzędzia elektronicznego platformy LimeSurvey, zamieszczonej na serwerze UKSW, nadzorował także jej przebieg i respons od uczestników badania. Fakt wielostronnej współpracy środowiska socjologów w projektach badawczych PPPiW pozwala na podniesienie kompetencji analitycznych w praktyce i ułatwia wymianę doświadczeń, procentujących przy nowych inicjatywach.

Przygotowania do badania, w tym konceptualizacja, schemat pytań oraz forma surveyu, zapoczątkowano już w lutym bieżącego roku. Ich efektem było stworzenie elektronicznego kwestionariusza ankiety (typ CAWI - Computer Assisted Web Interview), który zawierał 30 pytań, w tym 11 z nich referowało cechy społeczno-demograficzne (tzw. ,metryczkowe”, takie jak m.in. płeć, wiek, stan cywilny, wykształcenie, rodzaj wykonywanej pracy i czas zamieszkania w Warszawie, ale także stosunek do wiary i praktyk religijnych, przynależność wyznaniowa, wiek dzieci, liczba dzieci na utrzymaniu). Warto zauważyć, że sposoby dotarcia do próby badawczej odbywały się za pośrednictwem ugruntowanej w metodologii socjologicznej „techniki kuli śnieżnej” (stosowanej wtedy, gdy dotarcie do respondentów jest utrudnione), ale także zdecydowano się na promocję badania przez serwis społecznościowy Facebook, co wydatnie zwiększyło zasięg dotarcia do badanej populacji. Skądinąd przyjęcie właśnie takich rozwiązań w metodologii socjologicznej spotkało się ostatnio z żywym odzewem i dyskusjami wśród socjologów na temat samego pomiaru i dostępu do badanych, jako zagadnień w obecnej sytuacji ograniczania kontaktów wręcz kluczowych dla przyszłości badań jako takich ${ }^{14}$.

Podstawowa struktura społeczno-demograficzna badanej próby z populacji przedstawia się następująco: $\mathrm{w}$ surveyu wzięło udział znacznie więcej kobiet (63,9\%) niż mężczyzn (36,1\%), badani oznaczyli swoje grupy wieku w przedziałach: 18-29 lat (32,2\%), 30-45 lat (35,2\%), 46-59 lat (20,8\%), 60

14 Przykładem może być niedawna konferencja Instytutu Filozofii i Socjologii Polskiej Akademii Nauk (IFiS PAN) zatytułowana Metodologiczne Inspiracje 2021. Badania Ilościowe w Naukach Społecznych - Wyzwania i Problemy, która odbyła się w dniach 23-24 września 2021 r. w Jabłonnie pod Warszawą. Podczas jej obrad zastanawiano się m.in. nad problematyką doboru losowego przez reklamy Facebooka (referat B. Jancewicz) czy też odchodzeniem od sondaży face-to-face w warunkach pandemii, czyli ograniczonej możliwości realizacji badań tradycyjnych, opartych na osobistym kontakcie badacza z respondentami (referat A. Rybaka). 
lat i więcej (11,7\%), a swój stan cywilny zadeklarowali jako kawalerowie/ panny $(34,2 \%)$, żonaci/zamężni (39,9\%), osoby owdowiałe $(1,2 \%)$, rozwodnicy $(6,9 \%)$ oraz pozostający w związku partnerskim $(17,8 \%)$. Poziom wykształcenia badanych to podstawowe $(0,3 \%)$, zasadnicze zawodowe $(0,7 \%)$, średnie $(25,2 \%)$, wyższe licencjackie $(14,2 \%)$, wyższe magisterskie $(59,6 \%)$. Sytuację zawodową ankietowanych można zdefiniować na podstawie ich wskazań: umowa o pracę, czyli etat (57,3\%), umowa zlecenie (7,4\%), własna działalność gospodarcza $(8,9 \%)$, osoby deklarujące się jako bezrobotne $(2,3 \%)$, renciści $(0,3 \%)$, emeryci $(7,6 \%)$, uczniowie/studenci $(16,2 \%)$. Co ciekawe, uczestnicy badań najczęściej podawali zdalną pracę wykonywanej pracy zawodowej (32\%), następnie pracę hybrydową (27,1\%), stacjonarną (19,1\%). Warto odnotować, że tego rozróżnienia nie podało $21,8 \%$ respondentów. Ilość dzieci w gospodarstwie domowym podawano jako: jedno $(14,7 \%)$, dwoje $(16,7 \%)$, troje i więcej $(5,1 \%)$. Natomiast brak posiadania dzieci zadeklarowało aż 63,5\% ankietowanych. Badani zaanonsowali również swoją przynależność wyznaniową: rzymskokatolicką $(55,3 \%)$, prawosławną $(0,8 \%)$, protestancką $(0,8 \%)$, mojżeszową $(0,5 \%)$ oraz - w dużym stopniu - inną od wymienionych (42,6\%). Do zasobu tych danych należy z pewnością dołączyć czas zamieszkania w Warszawie: 0-5 lat (12\%), 6-10 (9,6\%), 11-20 (18,3\%), powyżej $20(60,1 \%)$.

Badanie posiadało charakter pomiaru eksploracyjnego, a zebrany materiał empiryczny pozwolił na przeprowadzenie bardziej pogłębionej analizy, która zostanie przedstawiona $\mathrm{w}$ aktualnie przygotowywanej publikacji postbadawczej, mającej ukazać się planowo pod koniec 2021 r. Nowa pozycja zostanie dołączona do serii publikacyjnej PPPiW, która obecnie liczy już osiemnaście tomów.

\section{Struktura tematyczna narzędzia badawczego}

Jak już wspomniano, kwestionariusz ankiety składał się ogółem z 30 pytań. Co istotne, na samym początku serii pytań tematycznych, po zdiagnozowaniu podstawowych danych społeczno-demograficznych, zdecydowano się na postawienie pytania „wstępnego", gdzie respondenci zostali poproszeni o oszacowanie zmian w poszczególnych obszarach ich życia. Odpowiedzi na to pytanie były pewnym odniesieniem do bardziej szczegółowych danych, uzyskanych w następnych, pogłębionych pytaniach tematycznych.

Modułowy charakter narzędzia badawczego skonstruowany został tak, aby po pytaniach o dane społeczno-demograficzne respondenci zaznaczyli te obszary, jakie ich zdaniem uległy modyfikacji. Biorąc pod uwagę wszystkie odpowiedzi pozytywne (zarówno zdecydowane, jak i mniej 
kategoryczne), można uszeregować te odpowiedzi następująco: udział w kulturze i praktyki życia codziennego $(85,1 \%)$, edukacja i życie zawodowe $(68,1 \%)$, relaks i odpoczynek $(66,9 \%)$, aktywność fizyczna $(65,6 \%)$, relacje z innymi (64,5\%), troska o zdrowie (62\%), życie emocjonalne $(58,1 \%)$, życie rodzinne (53,3\%), życie małżeńskie/partnerskie (32\%). Widać więc zatem, że większą popularnością cieszyły się wskazania obszarów „na zewnątrz" od sfer środowiska rodzinnego - grupy pierwotnej.

Następnie - po „wejściu” respondentów w tematykę badań - starano się pogłębić zaznaczone na wstępie obszary. Każde z pytań zostało sformułowane w ten sposób, aby respondenci mogli rzeczywiście wykazać konkretne zmiany. Podawano zatem uczestnikom badania określone opinie w ramach każdego tematycznego pytania i proszono, aby odnieśli się do każdego z twierdzeń. Zgodnie z metodologią badań ilościowych kwestionariusz miał formę zamkniętą, a ankietowani mogli najczęściej wybrać odpowiedzi uszeregowane w tzw. skalę Likerta (,zdecydowanie tak” - „,raczej tak” - „trudno powiedzieć” - „raczej nie” - ,zdecydowanie nie”). Kierując się logiką pytań, w niektórych obszarach dodawano odpowiedzi ,nie dotyczy", aby uwiarygodnić tym samym różne odniesienia osób badanych do rodzaju tematyki (np. posiadanie dzieci). W niektórych pytaniach wariantowych zdecydowano się na inny niż podany wyżej rozkład odpowiedzi, też uwzględniając sens pytań i ich kontekst (np. wyrażenia „częściej niż przed pandemią”, ,rzadziej niż przed pandemią”, ,bez zmian” lub „,bardzo mi brakuje”, „raczej mi brakuje”, „,raczej mi nie brakuje”, ,zdecydowanie mi nie brakuje"). Takie ułożenie odpowiedzi powoduje lepsze rozeznanie w tematyce i brak monotonii dla uczestników badań, zresztą nie ma możliwości zachowania jednego typu odpowiedzi w całym narzędziu badawczym, chociażby ze względów czysto językowych.

\section{Charakterystyka wybranych danych}

Przedstawione poniżej dane cząstkowe nie będą odnosiły się do wszystkich tematycznych bloków badania, które zostały opisane powyżej. Autorzy skupią się na ukazaniu jedynie kilku obszarów, które pokazują przede wszystkim samo sedno projektu badawczego, czyli sfery relacji z innymi, życia zawodowego oraz udziału w kulturze i praktyk życia codziennego. Do tego zestawu należy też zaliczyć odniesienie do religii i religijności oraz obecnych kwestii społecznych bardzo akcentowanych w przestrzeni publicznej (protesty uliczne).

Przechodząc do konkretnych wskazań respondentów, należy zaznaczyć, że zaczynały się one od sfery relacji z innymi. Ankietowani w większości 
wskazali, że pandemia nie przyczyniła się istotnie do osłabienia relacji z rodziną (,zdecydowanie tak" - 6,6\%, „raczej tak” - 16,3\%, „trudno powiedzieć" - 9,4\%, „raczej nie”-36,8\%, ,zdecydowanie nie”-30,9\%). Dużo większe znaczenie pandemii w dekompozycji relacji widać chociażby w gronie przyjaciół (odpowiednio: 14,7\%, 30,4\%, 11,9\%, 29,4\%, 13,7\%). Poczucie osamotnienia w pandemii akcentowało $26,7 \%$ badanych, a zdecydowanie ponad połowa miała zdanie przeciwne $(61,7 \%)$. Jeśli chodzi o doświadczenie wsparcie ze strony rodziny, to w tym przypadku rozkład odpowiedzi był następujący: „zdecydowanie tak” - 34\%, ,raczej tak”$38,1 \%$, „trudno powiedzieć” - 16,2\%, „raczej nie”-8,1\%, „Zdecydowanie nie" $-3,6 \%$. Z kolei wsparcie ze strony przyjaciół, znajomych i sąsiadów zadeklarowało odpowiednio $20,1 \%, 35,3 \%, 19,1 \%, 19,5 \%, 5,9 \%$. Ponadto ankietowani zadeklarowali, że w czasie pandemii raczej nie ograniczają nadmiernie spotkań z bliskimi osobami (zbiorczo „tak” - 47,9\%, „nie” $40,4 \%$ ). Podobnie przedstawia się kwestia przeniesienia wszystkich relacji ze znajomymi do sieci - również tutaj ponad połowa badanych $(53 \%)$ odpowiada przecząco.

Ankietowani wyznają, że w większym stopniu brakuje im bezpośrednich spotkań z innymi (,zdecydowanie tak”-37,5\%, „raczej tak”-28,4\%, „trudno powiedzieć” - 9,6\%, „raczej nie” - 15,7\%, „Zdecydowanie nie” 8,9\%). Ale już w zdecydowanej większości nie poznają dzięki pandemii większej ilości osób niż wcześniej (odpowiednio: 3,5\%, 5,9\%, 10,1\%, 32,3\%, $48,2 \%$ ), co może być niejako zaskoczeniem. Badani w mniejszym stopniu waloryzują też wirtualne przyjaźnie (odpowiednio: 9,2\%, 12,9\%, 16,8\%, $26,4 \%, 34,7 \%$ ), a wręcz unikają szukania w sieci miłości i bliskości (odpowiednio: $2,5 \%, 6,1 \%, 5,9 \%, 16 \%, 69,5 \%)$. Z kolei duża część ankietowanych nie ma sprecyzowanego zdania odnośnie zwiększonej dbałości o relacje z innymi w dobie pandemii (34,3\% - odpowiedź „trudno powiedzieć”). Niemniej jednak należy także odnotować prawie dwukrotnie większą częstotliwość zwracania większej uwagi na potrzeby innych osób i deklarowaną im chęć pomocy (44,9\%), niż stanowiska przeczącemu zwiększonej uwadze (20,9\%). Wirtualizacja ma zatem różne odcienie wpływania na relacje, na pewno jednak jest ona czynnikiem istotnym chociażby w podejściu do relacji poza pierwotną grupą rodzinną - szczególnie tych nawiązywanych w kręgu rówieśniczym.

Przechodząc do sfery pracy zawodowej, należy na wstępie podać ogólny stosunek do jej zdalnej formy. Z uzyskanych danych wynika, że jest on dużo bardziej pozytywny (ogółem 58,1\% odpowiedzi, w tym zdecydowanych 37,3\%, a mniej kategorycznych 20,8\%), niż negatywny (ogółem $17,5 \%$ odpowiedzi, w tym zdecydowanych $7,8 \%$, a mniej kategorycznych 
9,7\%). Zdania na ten temat nie sprecyzował z kolei więcej niż co dziesiąty uczestnik badań (10,7\%). Także w metropolitalnym środowisku warszawskim wypowiadano się o pracy zdalnej raczej pozytywnie niż negatywnie, skupiając się bardziej na pozytywach takiego rozwiązania.

Dla badanych warszawiaków pandemia w większości nie oznaczała radykalnego zmniejszenia standardu życia - znacznie więcej osób nie odnotowało pogorszenia własnej sytuacji materialnej (63,4\% wszystkich odpowiedzi, w tym 32,7\% formułowanych zdecydowanie, a 30,7\% w sposób mniej kategoryczny). Przeciwstawny pogląd, w którym stwierdzono pogorszenie sytuacji materialnej wyraziło znacznie mniej respondentów - w liczbach ogólnych ponad trzykrotnie mniej-odpowiednio 18,7\%, 8,6\% i $10,1 \%$. Swojego zdania w pełni nie wyraziło $8,4 \%$ ankietowanych, a kwestia ta nie dotyczyła $9,6 \%$ osób uczestniczących w badaniu.

Ankietowani w większości nie obawiają się również aż tak bardzo utraty pracy. Ogółem tego stanu rzeczy obawia się jedynie bowiem nieco więcej niż co dziesiąty badany $(11,4 \%$ ), w tym w sposób zdecydowany wyraża to $5,1 \%$ indagowanych, a mniej kategoryczny $6,3 \%$. Odpowiedzi przeciwne (wyrażające brak obaw) są znacznie częściej podnoszone - odpowiednio $57,2 \%, 27,7 \%, 29,5 \%$. Także różnica $\mathrm{w}$ tym względzie jest ponad pięciokrotna na korzyść osób nie akcentujących obaw o utratę pracy. Warto również dodać, że odpowiedzi ,trudno powiedzieć” udzieliło 9,6\% ankietowanych, a „nie dotyczy” aż 21,8\%. Z danych ogólnych wynika zatem raczej optymistyczne spojrzenie na dostępność pracy w metropolitarnym środowisku miejskim.

Powyższe informacje można skonfrontować z opiniami odnośnie zmiany zawodu. Nie potwierdziły się tutaj założenia funkcjonujące chociażby w publicystyce, które wykazywały, że pandemia Covid-19 może być ważnym powodem czy też głównym katalizatorem zmian zawodu. We wskazaniach ogólnych można dostrzec, że dużo większa liczba respondentów nie zaanonsowała tej możliwości - ogółem było to 50,3\% odpowiedzi, w tym $33,3 \%$ zdecydowanie negatywnych, a 17\% mniej kategorycznych. Przeciwnego zdania jest odpowiednio 18\%, 6,8\%, 11,2\% badanych. Respondenci, którzy nie określili swojej wypowiedzi, stanowili 7,4\%, natomiast odsetek odpowiedzi ,nie dotyczy” wyniósł 24,3\%.

W dobie pandemii - poza pracą zawodową - również sfera uczestnictwa w kulturze oraz praktyk życia codziennego uległa przeobrażeniom. Przede wszystkim znów należy tutaj odnieść się do konieczności opuszczania w miarę bezpiecznych miejsc izolacji, a wszystkie aktywności ,zewnętrzne” wiążą się z ryzykiem epidemicznym. Jednak w tym przypadku zróżnicowanie opinii wiąże się z możliwością zastąpienia danej aktywności, np. 
poprzez rozwiniętą współcześnie technologię umożliwiającą komunikację i udostępnianie treści - dawniej dobra te były dostępne jedynie w instytucjach lub miejscach poza domem.

Widać to doskonale w gradacji opinii i postaw wobec: (1) chodzenia do kina („,bardzo mi brakuje”-24,1\%, ,raczej mi brakuje” - 34,5\%, „trudno powiedzieć" $-6,8 \%$, ,raczej mi nie brakuje” $-22,8 \%$, ,zdecydowanie mi nie brakuje" - 11,9\%); (2) chodzenia do teatru (odpowiednio: 24,9\%, 31,7\%, $9,9 \%, 17,7 \%, 15,8 \%)$; (3) chodzenia na wystawy, do galerii (odpowiednio: $18,6 \%, 29,9 \%, 10,4 \%, 25,9 \%, 15,2 \%) ;(4)$ uczestnictwa w koncertach na żywo (odpowiednio: 28,2\%, 23,4\%, 9,9\%, 21,9\%, 16,5\%); (5) uczestnictwa w imprezie sportowej na żywo (odpowiednio: 8,6\%, 12,2\%, 10,4\%, 26,4\%, 42,4\%); (6) spotkań w klubach, zorganizowanych imprez (odpowiednio: $20,3 \%, 25,2 \%, 9,2 \%, 22,4 \%, 22,8 \%)$; (7) wyjść do restauracji, pubów (odpowiednio: $52 \%, 31,4 \%, 5 \%, 5,6 \%, 5,4 \%$ ); (8) swobodnego chodzenia na zakupy np. do galerii handlowej (odpowiednio: 29,2\%, 30,5\%, 9,6\%, 19,5\%, 11,2\%); (9) korzystania z usług salonów fryzjerskich/kosmetycznych/ spa (odpowiednio: 24,4\%, 31,4\%, 10,7\%, 19,1\%, 14,4\%); (10) korzystania z centrów rozrywki dla rodzin, gdzie znajdują się sale zabaw, kręgielnie itp. (odpowiednio: 11,9\%, 16,2\%, 11,4\%, 22,4\%, 38,1\%); (11) swobodnego podróżowania po kraju i za granicę (odpowiednio: 59,4\%, 22,6\%, 5,9\%, $7,1 \%, 5 \%)$.

Pewnym zaskoczeniem może tutaj być stosunkowo mała deprywacja uczestnictwa w imprezie sportowej na żywo (brak tej formy aktywności wyraża jedynie nieco ponad co piąty badany -20,8\%). Natomiast najczęściej badanym doskwiera brak wyjść do restauracji i pubów (83,4\% uczestników badań zaznaczyło taką możliwość), jak też brak swobodnego podróżowania (zarówno po kraju, jak i za granicę - 82\%). Widać zatem, jak bardzo spotkania „kawiarniane” i wyjazdy poza miejsce zamieszkania (podróże) są wrośnięte w styl życia i kulturę wielkiego miasta - dużo bardziej, niż np. uczestnictwa w wydarzeniach sportowych, które są udostępniane na wielu kanałach telewizyjnych czy internetowych i rozgrywanych nawet bez udziału publiczności. Stąd też w dobie pandemii taki dostęp może być pewną ,protezą" udziału rzeczywistego.

Na szczególną uwagę zasługują tu preferencje religijne, a dokładnie stosunek do wiary i praktyk religijnych. We wszystkich edycjach badań empirycznych prowadzonych przez Pracownię Badawczą PPPiW jeden z segmentów zarezerwowany był dla zagadnień religii i religijności. Tak też się stało się i tym razem, bowiem pytania o stopień zaangażowania religijnego w postaci autodeklaracji wiary i uczestnictwa w praktykach religijnych potraktowane zostały jako zmienne niezależne, które - jak 
wykazała dotychczasowa praktyka badawcza - wyraźnie dyferencjują postawy badanych.

Dlatego też, w narzędziu badawczym - już tradycyjnie - postawiono najpierw pytanie o stosunek do wiary i praktyk religijnych (łącznie wiara i praktyki religijne). Z takiego połączenia wynika, że co druga badana osoba zaliczała się do grona wierzących, ale jednocześnie o różnym stopniu zaangażowania religijnego $(51,2 \%)$. Wśród nich tylko co piąta określała się jako wierząca i praktykująca regularnie $(20,1 \%)$, co siódma jako wierząca, ale niepraktykująca (13,9\%), a co ósma ujawnia już tylko swoje przywiązanie do tradycji religijnej przy jednoczesnej obojętności wobec wiary (12,5\%). Jednocześnie badanie wyraźnie pokazuje wysoki odsetek osób niewierzących i niepraktykujących (36,3\%). Tym samym, co trzeci badany deklarował swój dystans wobec wiary i praktyk religijnych. W pewnym stopniu potwierdza się teza o słabnącej religijności mieszkańców wielkich aglomeracji.

W zrealizowanym badaniu postawiono również pytanie mające na celu rozpoznanie miejsca wiary religijnej w życiu codziennym badanych i to w szczególnym czasie - panującej pandemii Covid 19. Pytanie nosiło treść: „Proszę określić, jakie zmiany pandemia spowodowała w Pana/i życiu religijnym?". Pytanie to potraktowano jako opis własnej wiary i religijności, a respondenci mieli ustosunkować się do przedstawionych dziesięciu sformułowań, wybierając jedną z odpowiedzi na pięciostopniowej skali Likerta od „zdecydowanie tak” do ,zdecydowanie nie”.

Przeprowadzony pomiar ujawnił rozkład odpowiedzi (uwzględniając w tym miejscu tylko odpowiedzi ,zdecydowanie tak” i „raczej tak”) na następujące sformułowania: 1) Mimo tradycji, zastosowałem (-am) się do zasad i w ostatnie święta Wielkanocne nie odwiedziłem (-am) rodziny i przyjaciół $(46,1 \%) ; 2)$ Obecnie częściej rozmawiam na tematy religijne w rodzinie $(43,0 \%) ; 3)$ Wiara religijna bardziej niż kiedyś pozwala mi przezwyciężyć codzienne trudności (40,7\%); 4) Wspierałam duchowo (poprzez modlitwę) osobę/y znajdującą/e się w trudnej sytuacji życiowej (39,4\%); 5) Częściej zastanawiam się nad swoim i swoich najbliższych życiem w perspektywie wiary religijnej (30,8\%); 6) Pobożnie uczestniczyłem (-am) w mszach św., nabożeństwach i rekolekcjach transmitowanych w mediach $(29,1 \%)$; 7) Szukam w sieci (w Internecie) treści religijnych (24,1\%); 8) Obecnie częściej niż kiedyś modlę się prywatnie $(22,5 \%)$; 9) Na nowo odkryłem (-am) wartość wyznawanej religii (15,5\%); Częściej szukałem (-am) wsparcia duchowego u o osoby duchownej (7,8\%). Warto w tym miejscu zauważyć, iż wiara religijna nadal u wielu osób pełni rolę terapeutyczną i sensotwórczą. 
Jednocześnie zaś widać tu wyraźny dystans wobec osób duchownych, z którymi kontakt mógłby dostarczyć wsparcia w tym trudnym czasie pandemii.

Dodatkowo zespół pracowni badawczej PPPiW zapytał, w jakim stopniu respondenci odczuwali brak osobistego uczestnictwa w kościele w wybranych rodzajach kultu religijnego, co wynikało z wprowadzonych i obowiązujących limitów osób w przestrzeniach zamkniętych. Uczestnictwa w codziennej, niedzielnej bądź świątecznej mszy św. bardzo brakowało $17,1 \%$ badanym i tyle samo, bo $17,0 \%$ skłoniło się ku opcji ,raczej brakowało". Z kolei w nabożeństwach okolicznościowych (takich jak: majowe, czerwcowe, październikowe, droga krzyżowa) odsetki te kształtowały się odpowiednio: $6,5 \%$ i $11,7 \%$. Na osobną uwagę zasługuje liturgia pogrzebu, która w czasach przedpandemicznych zazwyczaj gromadziła w kościołach i miejscach kultu religijnego wiele - nawet obojętnych religijnie i niewierzących - osób. W tym wypadku odpowiedzi „bardzo mi brakuje” i ,raczej mi brakuje" wskazywały odpowiednio kolejne odsetki badanych: 12,7\% i 15,3\%. Wynika z tego, że niejednej osobie przychodziło z trudem pogodzić się z sytuacją niemożności pożegnania zmarłego podczas obrządku religijnego.

Okazało się, że identyfikacje religijne, albo inaczej stosunek do wiary religijnej i jej funkcji jaką jest religijność, korelowały - co założono na etapie konceptualizacji badań - z opiniami na temat protestów ulicznych po orzeczeniu Trybunału Konstytucyjnego. Dlatego też, kolejny segment w narzędziu badawczym zawierał pytania nawiązujące wprost do wydarzeń na ulicach miast Polski. Segment ten nazwany został „życie społeczne” i dotyczył zachowań zbiorowych, które uznano za ważne również z racji specyficznego czasu, bo okresu pandemii i obowiązujących obostrzeń, zakazów i limitów. Warto dodać, iż sama idea życia zbiorowego - podejmowana w rozważaniach socjologów nad życiem społecznym - obejmuje także zbiorowe wybuchy niezadowolenia, sprzeciw społeczny, dynamikę tłumu, którego znamienną cechą jest silny ładunek emocjonalny, a co w konsekwencji prowadzi na drodze interakcji do wyłaniania się norm społecznie nieakceptowalnych. W obszarze tych zagadnień lokuje się również problematyka ruchów społecznych i wywoływanych przez nie konflikty o charakterze aksjologicznym, o których socjolog Edmund Wnuk-Lipiński pisał, iż „tworzą się wokół roszczeń rozmaitych aktorów zbiorowych do tego, by ich system wartości dominował w życiu publicznym. Klasycznym przykładem konfliktu tego typu jest sprzeczność roszczeń zwolenników i przeciwników aborcji”' ${ }^{\prime 1}$. Z tych też powodów w zrealizowanym badaniu

15 E. Wnuk-Lipiński, Socjologia życia publicznego, Warszawa 2005, 254. 
dwa pytania odnosiły się do protestów ulicznych uznanych za ważne wydarzenia społeczne w życiu mieszkańców Warszawy. Pierwsze miało na celu spomiarowanie deklaracji czynnego udziału w nich, drugie zaś rozpoznanie poglądów i ocen respondentów na zachowania towarzyszące protestującym.

Trzeba przypomnieć, iż Trybunał Konstytucyjny w dniu 22 października 2020 roku orzekł o niekonstytucyjności przepisu dopuszczającego aborcję w przypadku dużego prawdopodobieństwa ciężkiego i nieodwracalnego upośledzenia płodu. Tym samym uznał, iż przepis tzw. ustawy antyaborcyjnej z 1993 r. zezwalający na usunięcie ciąży, gdy badania prenatalne lub inne przesłanki medyczne wskazują na prawdopodobieństwo ciężkiego i nieodwracalnego upośledzenia płodu albo nieuleczalnej choroby zagrażającej jego życiu, jest niekonstytucyjny. $Z$ tak sformułowanego orzeczenia wynika, iż legalizacja zabiegu przerwania ciąży, w przypadku, gdy badania prenatalne lub inne przesłanki medyczne wskazują na duże prawdopodobieństwo ciężkiego i nieodwracalnego upośledzenia płodu albo nieuleczalnej choroby zagrażającej jego życiu, nie znajduje konstytucyjnego uzasadnienia. Wydanie tegoż orzeczenia spowodowało, iż na ulicach wielu miast Polski - zarówno dużych, jak i małych - miały miejsce protesty, niekiedy wielotysięczne. Najliczniejsze z nich odbyły się w stolicy, ale również - na co warto zwrócić uwagę - niezadowolenie społeczne w postaci demonstracji pojawiło się także w wielu krajach, zwłaszcza tam, gdzie mieszka duża liczba Polaków.

Na pytanie, czy respondent uczestniczył w protestach ulicznych w ostatnim czasie, odpowiedzi twierdzącej udzieliło 35,6\% ankietowanych. $Z$ kolei pytanie drugie miało na celu poznanie stosunku badanych do protestów, oceny zachowań ich uczestników na ulicach, dodatkowo zaś poznanie poglądu respondentów na Kościół rzymskokatolicki, wskazywany tu jako autorytet instytucjonalny. Pytanie zawierające dziewięć sformułowań brzmiało: „W ostatnim czasie na ulicach Warszawy organizowane były manifestacje przeciwko orzeczeniu Trybunału Konstytucyjnemu w sprawie aborcji. Proszę powiedzieć, jak Pan/i ocenia poniższe zachowania związane z tą decyzją?". Przywoływane tu odsetki odpowiedzi uwzględniają jedynie pozytywne nastawienie respondentów, na co wskazywał wybór odpowiedzi bądź to „zdecydowanie uzasadnione” bądź „raczej uzasadnione”. 1) Według opinii $67,5 \%$ badanych protesty były zdecydowanie uzasadnione zaś według 11,4\% raczej uzasadnione, co daje łączny wynik akceptacji na poziomie $78,9 \%$. Pytając o postawy i zachowania protestujących, uzyskano następujące rozkłady deklaracji: 2) Nieprzestrzeganie wymagań sanitarnych podczas protestów było dla $54,6 \%$ badanych uzasadnione, przy czym według 36,8\% zdecydowanie uzasadnione; 3) Przekonanych 
o uzasadnionym nieprzestrzeganiu zakazu gromadzenia się na ulicach było $68,4 \%$, w tym zdecydowanych było aż 56,4\%; 4) Z kolei zwolenników wypisywania haseł na murach i drzwiach kościołów było $37,3 \% \mathrm{w}$ tym $27,9 \%$ uważało takie zachowania za zdecydowanie uzasadnione, a więc nienaganne; 5) Wkraczanie protestujących do kościołów podczas nabożeństw i mszy św. z plakatami i hasłami proaborcyjnymi nie budziło zastrzeżeń u 38,8\% badanych w tym działania takie zdecydowanie usprawiedliwiało 28,9\% badanych; 6) Za zdecydowanie uzasadnione bądź raczej uzasadnione postrzegało organizowanie grup obrony kościołów $23,0 \%$ respondentów; 7) Wypisywane wulgaryzmy na plakatach i transparentach znalazło poparcie u 57,1\% respondentów, w tym 40,9\% uważało takie działania za zdecydowanie uzasadnione; 8) Jednocześnie niemal tyle samo osób, bo $53,1 \%$, usprawiedliwiało pojawianie się wulgaryzmów w wypowiedziach i gestach publicznych; 9) I wreszcie, pogląd, że Kościół rzymskokatolicki jest nadal autorytetem instytucjonalnym znajduje uzasadnienie u $24,2 \%$ badanych, zaś zdecydowane uzasadnienie już tylko u 14,0\%.

Analiza materiału empirycznego potwierdziła założenia poczynione na etapie wstępnym, mówiące o możliwej zależności postaw społecznych (w tym wypadku protestów ulicznych) od identyfikacji religijnych. Mimo powszechnego wręcz poparcia dla owego zbiorowego wybuchu niezadowolenia, przeprowadzone korelacje pokazały, iż zdecydowanych zwolenników częściej można było spotkać wśród osób niewierzących i niepraktykujących. Niemniej nie wolno nam pominąć faktu, iż także osoby wierzące i regularnie praktykujące wyrażały swoje poparcie dla protestów wymierzonych w orzeczenie Trybunału Konstytucyjnego, wyrażone w akceptacji zachowań protestujących. Wyniki z pytań dotyczących wiary religijnej, religijności oraz protestów ulicznych pozwalają na sformułowanie ostrożnej tezy mówiącej o zmianie systemu wartości, bowiem religia wysoko ceniona w Polsce jeszcze przed 2-3 dekadami obecnie traci na znaczeniu, a krzywa braku akceptacji dla praktyk religijnych zdaje się przybierać już tendencję stałą.

\section{Konkluzja}

Warto zaznaczyć, że niniejsze badanie powstało na gruncie doświadczeń zespołu PPPiW z badań CAWI z 2020 r. Dotyczyły one młodzieży akademickiej (próba ogólnopolska, badanie zatytułowane Młodzież akademicka o rodzinie $i$ religii 2020), a sprawozdanie $\mathrm{z}$ tego projektu zamieszczono w numerze 4/2020 „Collectanea Theologica” (tom 90). Ponadto ukazały 
się (zapowiadane w zeszłorocznym sprawozdaniu) trzy monografie naukowe ${ }^{16}$, gdzie zaprezentowano pełne odniesienie się do danych uzyskanych w ramach tego badania. Zarazem było to już drugie badanie wykonywane w warunkach pandemii, gdzie sami respondenci byli pytani o jej wpływ na różne sfery życia: rodzinną, zawodową oraz koleżeńską. Starano się ukazać także motywy przewodnie w relacjach badanych ze swoim najbliższym otoczeniem społecznym.

Wracając do tegorocznego projektu badawczego, można powiedzieć, że stopień wirtualizacji i zastępowalności form rzeczywistych korelatami zdalnymi jest uzależniony od wielu czynników sytuacyjnych. Uczestnicy badań wykazali różne postawy i opinie na temat roli sieci w relacjach, pracy zawodowej czy też praktykach życia codziennego. Nie bez znaczenia jest tutaj uciążliwość nowej rzeczywistości i stopień reakcji na wprowadzane restrykcje, które po jakimś czasie są niwelowane przez rozwiązania pragmatyczne, pomagające w komunikacji nawet przy ograniczeniach formalnych.

$\mathrm{Z}$ kolei sfera religijności badanych oraz zachowań z przestrzeni życia publicznego charakteryzuje się dużą dynamiką. Dla uczestników badania ważnym odniesieniem były również protesty uliczne i różnorakie formy wyrażania akceptacji lub sprzeciwu wobec prezentowanych zagadnień światopoglądowych. Widać wyraźnie, że w środowisku metropolitalnym religia musi na nowo określić swoje miejsce, działając niekiedy w bardzo wymagających warunkach, dodatkowo w obliczu presji ze strony różnych środowisk stricte antykościelnych.

Jak już zostało wspomniane, aktualnie trwają pracę nad publikacją postbadawczą, w której przedstawiona zostanie pogłębiona analiza całego zebranego materiału empirycznego. Wszystkich Czytelników zachęcamy do lektury naszych opracowań i czerpania $\mathrm{z}$ dorobku badawczego pracowni PPPiW.

16 Zob. M. Kawińska, J. Wróblewska-Skrzek, A. Linek, Wolność wyboru czy przymus zwyczaju? Młodzież akademicka w dobie pandemii o związach, intymności i więziach rodzinnych, tom 1, Poznań 2020; S.H. Zaręba, W. Klimski, M. Sroczyńska, Wolność wyboru czy przymus zwyczaju? Młodzież akademicka $w$ dobie pandemii o religii, duchowości i moralności, tom 2, Poznań 2020; K. Uklańska, O.A. Kotowska-Wójcik, M. Choczyński, Wolność wyboru czy przymus zwyczaju? Młodzież akademicka $w$ dobie pandemii o sensie życia, relacjach i planach życiowych, tom 3, Poznań 2020. 